\title{
ANGELA MURRAY'S EXPERIENCE OF PASSING UP AS WHITE IN JESSIE REDMON FAUSET'S PLUM BUN
}

\author{
Ratna Asmarani \\ Faculty of Humanities - Diponegoro University \\ email: ratna_asmarani@yahoo.com
}

\begin{abstract}
The aim of this paper is to analyze the experience of Angela Murray, the female mulatto protagonist, when she finally decides to pass as a white person in Plum Bun, a novel written by Jessie Redmon Fauset. Considering that the focus of analysis is a female, the feminist literary criticism is used as the main framework. The contextual method of analysis is supported by some concepts concerning skin color and passing. The result shows that Angela goes through three periods of her existence. At first she plays with her skin color by passing temporarily as white with her mulatto mother. Then she decides to pass permanently as white and moves to a different state in which she is involved in an intimate relationship with a wealthy racist white man and humiliatingly hurts her younger black sister, her black female acquaintance, and the man she actually loves. Finally she confesses her true racial heritage and makes amends to the people she has hurt and finds the happiness she has sought so far.
\end{abstract}

Keywords: skin color, passing as white, racist, racial heritage

\section{PENGALAMAN ANGELA MURRAY MENJADI KULIT PUTIH DALAM PLUM BUN KARYA JESSIE REDMON FAUSET}

\begin{abstract}
Abstrak
Tujuan dari makalah ini adalah untuk mengkaji pengalaman Angela Murray, protagonis mulato perempuan, ketika ia akhirnya memutuskan untuk 'passing' atau menjadi kulit putih dalam novel berjudul Plum Bun karya Jessie Redmon Fauset. Mengingat bahwa fokus analisis adalah seorang perempuan, kritik sastra feminis digunakan sebagai kerangka utama. Metode analisis kontekstual didukung dengan konsep tentang warna kulit dan 'passing'. Hasil kajian menunjukkan bahwa Angela melewati tiga periode keberadaan. Awalnya ia bermain-main dengan warna kulitnya dengan 'passing' sementara sebagai orang kulit putih bersama ibunya yang mulato. Kemudian ia memutuskan untuk 'passing' sebagai orang kulit putih secara permanen dan pindah ke negara bagian lain di mana ia terlibat dalam hubungan intim dengan laki-laki kulit putih kaya yang rasis dan melukai hati adik perempuannya yang berkulit hitam, kenalan perempuan yang berkulit hitam, dan laki-laki yang sebenarnya dicintainya. Akhirnya ia mengakui warisan rasialnya dan menebus kesalahan pada orang-orang yang telah disakitinya dan menemukan kebahagiaan yang selama ini dicarinya.
\end{abstract}

Kata kunci: warna kulit, 'passing' sebagai kulit putih, rasis, warisan rasial 


\section{INTRODUCTION}

Skin color has an important meaning in the life of colored people, especially for the females, living in the still racist society of America in the 1930s. Having a light skin is often considered as a merit because the normative standard is being white. Being able to mingle or to enter the closed white circle is a dream for many lightskinned females because it is believed to open to an easy, luxurious, and prestigious life. Jessie Redmon Fauset (1882-1961), a perceptive African American female writer, portrays the hidden desire to be able to belong to the white class in her novel entitled Plum Bun (published 1929). She keenly describes the life of Angela Murray, the fair-skinned young woman, who decides to pass up permanently as white and moving to New York leaving her younger black-skinned sister in Philadelphia after the death of their parents. Joining the elite white community in New York, Angela Murray changes her name into Angéle Mory. She faces a humiliating experience with her wealthy racist white lover leading to her pondering her decision to hide her racial heritage and to abandon her blackskinned sister. Based on this concise story line, it is challenging to analyze the many faceted experiences of Angela Murray before and after she decides to pass up as a white and later her final decision to acknowledge her racial origin.

The issues of skin color and passing as white have attracted many experts to ponder seriously. Brown (1969) blatantly says that black people live in a racist society that judges people from the color of the skin (p. 2 in Berzon, 1978, p. 3). Thus, in the dichotomy of black and white identities, white people automatically gain in- numerable advantages (Hobbs, 2014, p. 11). Those advantages attract light-skinned person to pass as white. According to Wald (2000) "passing" means traversing the color line or switching into whites to avoid degrading racial attitude and treatment ( $\mathrm{p}$. 6). In other words, the action of passing as white is used as a means to have a much better life, chance, and future for the mixedraced people.

\section{METHODS}

To analyze the mixed-blood female character, the frame of analysis used is feminist literary criticism which analyzes the works of art from the perspective of women (Humm, 1995, p.51). A descriptive and qualitative analysis is applied to analyze the data from the novel entitled Plum Bun by Jessie Redmon Fauset. To get maximum result, a contextual analysis is chosen (Beard, 2001, p. 6) in which, based on the focus of analysis, the text is situated in its racial context. Data from the novel are collected using close reading. The data collection is based on the criteria of triggers, manifestations, and impacts of passing up and later of backing away from passing up as a white female. Then, each group of data is analyzed and linked to the analysis of the other group of data. Finally the whole analysis is concluded.

\section{FINDING AND DISCUSSION}

Angela Murray, the female mulatto protagonist, has three phases in her life in relation to her skin color. At first, she just passes up temporarily, playing with the privilege given by her light-skinned color, together with her mulatto mother. The she decides to pass up permanently as white, leaving her dark-skinned sister and her 
community. After having humiliating relationship with a white racist lover and feeling exiled by the colored people, finally she decides to acknowledge her racial origin at whatever consequences.

\section{A Brief Glance of Angela Murray}

Angela Murray is the eldest daughter of Junius Murray, a black man, and Mattie Murray, a mulatto. She has light skin like the mother, but her younger sister, Virginia Murray has dark skin like the father (Fauset, n.d., p. 14). Angela is described as follows "Angela had received not only her mother's creamy complexion and her soft cloudy, chestnut hair, but she has taken from Junius the aquiline nose, the gift of some remote Indian ancestor which gave to his face and his eldest daughter's that touch of chiseled immobility" (Fauset, n.d., p. 14). Angela Murray is what Kennedy (2001) calls as "white Negro" (p. 1).

They live modestly in a small house in the suburb of Philadelphia. While Virginia likes to go "exploring old Philadelphia" (Fauset, n.d., p. 16) with her father, Angela enjoys shopping with her mother and she craves "to know light, pleasure, gaiety and freedom" (Fauset, n.d., p. 13). Angela has a fallacious thought that "First, that the great rewards of life--riches, glamour, pleasure,--are for white-skinned people only. Secondly, that Junius and Virginia were denied these privileges because they were dark" (Fauset, n.d., p. 17) without realizing the core truth "that her father and sister did not care for this type of pleasure" (Fauset, n.d., pp. 17-18). Angela feels that her light skin is the ticket to gain those privileges and someday she will make it happen. Angela's opinion is in line with the opinion of Berzon (1978) that black people can pass as whites provided they have certain physical characteristics (p. 6).

\section{Angela's Playing with Her Skin-Color}

Since she was young, Angela is different from her younger sister who enjoys the domestic work, the warmth of family life, the routines of going to church, and the religious life. Little Angela learns how to utilize her light skin inherited from her mulatto mother (Fauset, n.d., p. 14). However, she totally does not understand that her mother's purpose of using her light skin to temporarily pass as white and enjoy certain privileges not allowed for black is "due merely to a mischievous determination to flout a silly and unjust law" (Fauset, n.d., p.15). Her mulatto mother is not serious in her passing as white. She just wants to ridicule the white rule that segregates whites and blacks. In other words, her mother's action is just for fun "my old game of play-acting" (Fauset, n.d., p. 19). It is just a temporary game of performance. In other words, the action of Angela's mother agrees with the opinion of Wirth and Goldhamer (1944) that sometimes fair-skinned person may pass as white unintentionally just for temporary fun (p. 303 in Sollors, 1997, pp. 250-251).

Her father, knowing precisely that it is just a kind of role play for amusement, has no objection to her mother's temporary passing as white "where no principle was involved, your passing means nothing to me. It's just a little joke" (Fauset, n.d., p. 19). As a harmonious couple, the black husband and the mulatto wife not only understand each other, but also deeply trust each other. The black husband does not feel dejected or abandoned by her mulatto wife's little excursions to the white 
surroundings. He knows precisely that his mulatto wife that he has married for years "had no desire to be one of these [white] people" (Fauset, n.d., p. 15). As for the mulatto wife, her husband is her soul mate, the one and only partner for her "her black husband ... she had been glad and proud to marry" (Fauset, n.d., p. 14). They love each other so deeply and thoroughly that for the mulatto wife "I'd give my life for him" (Fauset, n.d.., p. 56). They are inseparable, even though their skin color has a quite significant difference.

The mother, accompanied by Angela, continues her habits to have Saturday excursions to the places prohibited to the blacks. They dress elegantly and meticulously for the occasion so that they become such an enchanting sight for the passersby "A thin stream of people constantly passing threw an occasional glance at the quietly modish pair, the well-dressed, assured woman and the refined and no less assured daughter" (Fauset, n.d., p. 18). In other words, their appearance has no trace of their racial heritage at all. They look like classy white people.

Besides the appearance, they also self-confidently carry out activities commonly done by classy white ladies in their leisure time, that is "had browsed among the contents of the small exclusive shops in Walnut Street; they had had soda at Adams' on road Street" (Fauset, n.d., p. 18). Mother and daughter perfectly imitate the leisure activities of middle-class white ladies. They so often do this temporary passing around that area so that when they are standing elegantly in front of a classy hotel for a moment before continuing the excursion, "the door-man knew them" (Fauset, n.d., p. 18). The mother even often gives him "a small tip" like what a rich white lady does that makes the door man so grateful. All of these activities, attitudes, and demeanors are deeply memorized by Angela who enjoys so much these Saturday excursions.

Angela, however, takes the temporary passing with her mulatto mother seriously. One event confirms her fallacious thought. It unexpectedly happens when she and her mulatto mother are passing as white. Suddenly, they are almost face to face with father and Virginia. However, father and Virginia quickly disappear before her mother greets them. This leads Angela insensitively comment as follows: "It's a good thing Papa didn't see us, you'd have had to speak to him, wouldn't you" (Fauset, n.d., p. 18) assuming that the mother is not willing to address her black husband and black daughter. This ingrained fallacious thought emerges in Angela's dreaming "Angela, dreaming excitedly of Saturdays spent in turning her small olive face firmly away from peering black countenances" (Fauset, n.d., p. 19). The dream indicates that Angela, if there is a chance, without any doubt will shake off any bond with the black people.

\section{Angela's Passing as White}

Angela, who is "lack of openness" (Fauset, n.d., p. 34), secretly has an accumulated desire to pass as white. Several personal humiliating moments as black person with a light skin strengthen her desire to completely pass as white in a place where nobody knows her before.

The first humiliating moment is when she was still in high school. Angela's aloofness makes her having just a few friends. One of them is a new white student, Mary 
Hasting. Their closeness triggers the jealousy of Esther Bayliss, another female white student who has known Angela for a long time. To shatter their friendship, in front of other students Esther reveals to Mary that Angela is not white. Shocked, Mary, the white student, addresses Angela accusingly. The scene always haunts Angela:

"Coloured! Angela, you never told me that you were coloured!"

And then her own voice in tragic but proud bewilderment. "Tell you that I was coloured! Why of course I never told you that I was coloured. Why should I" (Fauset, n.d., p. 38)

Angela is deeply humiliated by this event and it makes her start thinking that it is better that "the fact of your racial connections was not made known" (Fauset, n.d., p. 46).

The second humiliating event happens when she is in the Art Academy. The person doing the humiliating action is the same, Esther Bayliss, who becomes the model of painting but immediately refused because she does not want "to lower myself to pose for a coloured girl" (Fauset, n.d., p. 71). A similar ignominious moment occurred when the white instructor, Mr. Shields reacts the same as Mary's in high school:

He blurted out miserably, "But, Miss

Murray, you never told me that you were coloured."

She felt as though she were rehearsing a well-known part in a play. "Coloured! Of course I never told you that I was coloured. Why should I?" (Fauset, n.d., p. 73).

Angela's almost similar respond on the first and second humiliating experiences reflects the opinion of Wirth and Goldhamer (1944) (p. 301 in Sollors, 1997, p. 251) that the mistaken identification by others is not directly corrected because the person has no chance, because the timing is not right, or because person is not disadvantaged.

The third embarrassing situation is when she goes with Matthew Henson, a coloured young man, to a movie used to be free for blacks. The white attendant does not allow Matthew to enter because "the management's changed hands since then, and we're not selling tickets to coloured people" (Fauset, n.d., p. 75). This event makes Angela feel sorry for Mathew and makes Matthew feel deeply disgraced in front of the girl he is infatuated with.

Another shameful situation for Angela is that she cannot accept the white acquaintances' invitation to their house because that means she has to invite them back to her house leading to their knowing that she has black racial heritage (Fauset, n.d., p. 81). The ignominious events steel Angela's decision compressed in her emotional sentence "This is the end" (Fauset, n.d.:, p. 76). Angela's strong decision to leave behind all the degrading reactions from the white reflects Stonequist's statement (1961) that the mixed-race people with light skin color can pass as whites intentionally with the purpose to escape from the limiting condition of life (p. 194 in Sollors, 1997, pp. 250-251)

Angela decides to pass as white. First she tells Virginia, her younger black sister, that: "I'm going to leave Philadelphia, give up school teaching, break away from our loving friends and acquaintances" (Fauset, n.d.: Fauset, n.d., p. 77). At that time only the two of them live in their parents' house 
after their parents, who loves each other so dearly, dies sequentially because they cannot be separated from each other. To the aghast Virginia, Angela pours out the deep dissatisfaction that she has felt so long: "I'm sick, sick, sick of seeing what I want dangles right before my eyes and then of having it snatched away from me and all of it through no fault of my own" (Fauset, n.d., p. 77) and her conclusion that "it isn't being colored that makes the difference, it's letting it be known" (Fauset, n.d., p. 78). Thus, in their parting "An indefinable steeliness was creeping upon them" (Fauset, n.d., p. 82). Sisters with different skin colors are cruelly separated by the strong desire of the fair-skinned one to totally pass as white.

Angela chooses New York "where she could by no chance be known, and launch out "into a freer, fuller life"" (Fauset, n.d., p. 80). She gets their parents' insurance money, because she needs cash money, while Virginia gets the house (Fauset, n.d., p. 81). After being idle and living lavishly for several days in NY, Angela who feels that "She was young, she was temporarily independent, she was intelligent, she was white" (Fauset, n.d., p. 88) finally pursuing her goal as a portrait painter by entering an art class. She changed her name into Angéle Mory (Fauset, n.d., p. 94). Angela's decision to pass totally into white by disowning her relationship with the blacks implies Williams' opinion (2004) that the intentional passing can be conducted by carefully hiding the racial heritage in order to construct improved existence (p. 167).

However, her seriousness in studying painting is deflected by her sudden thought when she arrives in NY "perhaps it's better to marry ... a white man" (Fauset, n.d., p. 88). Her acquaintanceship with Roger Fielding, a wealthy young white man (Fauset, n.d., p. 128), seems to realize her dream to join the white elite society. Angela's changing opinion in her aim to improve her life in the white circle is detected by Stonequist (1961), who states that these mixed-race people with light skin color can pass as whites intentionally with the purpose to gain the benefits through marriage (p.194 in Sollors, 1997, pp. 250-251)

Nevertheless, her dream is still a long way from coming true. It is true that Roger who is "so gay, so beautiful, like a blond, glorious god, so overwhelming, so persistent" (Fauset, n.d., p. 130) is giving her nice gifts and taking her to elite places, even offering her to move to a bigger apartment with a maid (Fauset, n.d., p. 183). However, Roger, who has many experiences with women, never offers a marriage proposal to her (Fauset, n.d., p. 167). According to her friends who know Roger, he will not dare to marry someone without his father consent because his father is "crazy about his name ad posterity ... insist on blue blood and the Mayflower" (Fauset, n.d., pp. 128-129). Besides, Roger is a true sickening racist. This can be seen in the restaurant's incident where he arrogantly orders the manager to drive away the coming black customers:

Roger came back, his face flushed, triumphant, "Well I put a spoke in the wheel of those 'coons'! They forget themselves so quickly, coming in here spoiling white people's appetites. I told the manager if they brought one of their damned suits I'd be responsible" (Fauset, n.d., p. 134). 
Roger's racist attitude to the black customers in the restaurant clearly indicates "Racial Arrogance" as stated by DiAngelo (2011, p. 61). However, the obvious racist attitude, words, and thought of Roger do not make Angela keep away from him. Instead, she becomes Roger's lover and soon her life only revolves around Roger "She was not curious about his money nor his business but she thirsted to know how his time away from her was spent, whom he saw, what other places he frequented" (Fauset, n.d., p. 205). Roger is her only world. Angela has no life of her own.

Angela's possessive attitude triggers Roger's "sullenness, remoteness, wariness" (Fauset, n.d.: 228) because he knows what Angela aims at, that is, "marriage" (Fauset, n.d., p. 228) and he does not have any intention to disobey his father's rule about his future wife. The climax of "the sweeter for that secrecy" (Fauset, n.d., p. 191) relationship is that Roger humiliatingly abandons Angela after he conspicuously flirts with a white girl of a rich family in front of Angela. To Angela's words demanding explanation, Roger condescendingly says: "No women with an ounce of pride would have stood for what you've been standing lately ... You know perfectly well what you were letting yourself in for. Any woman would know it" (Fauset, n.d., pp. 232233). Although Angela does not love Roger, since her willingness to be sexually involved with Roger is based on an illusion to have a perfect life with a rich white man, she is disgraced by Roger's words and her pride is shattered. Angela is in the situation as stated by Berzon (1978) that mixed-race people faces particular benefits and detriments in the relationship whether within the black or white society (p. 8).
Left alone on her own, Angela soon feels lonely since she has very limited friends. Her relationship with Roger has hurt not only herself but also some people around her which is mostly due to her secrecy about her racial heritage. For example, in NY railway station, Angela deeply hurts her younger black sister. With the purpose of picking up Virginia who comes to NY to have an examination for her future job, Angela is suddenly face to face with the racist Roger. To keep their present blooming relationship runs smoothly, Angela deliberately ignores her younger black sister who is standing in front of them, leaving Virginia "after a second's bewilderment but incredulous stare was quicker than they. Her slight figure, her head high, preceded them; vanished into a telephone booth" (Fauset, n.d., p. 160). Angela's action of not acknowledging her black sister in front of the white racist Roger agrees with Sollors' statement (1997) that the action of passing can be done in total secrecy or partial one by imploring others to help covering the secret (p. 251).

When Angela visits Virginia in her boarding house to atone her absolutely improper attitude, Virginia "had neither kissed nor offered to shake hands with her sister, yet her manner was friendly enough, even cordial" (Fauset, n.d., p. 165). Her attitude hides her deeply hurt feeling indicated by her harsh words "you cut your own sister" (Fauset, n.d., p. 166) in commenting Angela's action to keep her lover. The relationship between the sisters who has rifted when Angela decides to separate herself from her black sister is now completely broken. Now they live in the same city, but they are drifted far apart, Angela lives in the white community while Virginia 
enjoys the Harlem. The cold relationship between siblings reflects the damaging effects of hiding the racial heritage to the black relatives and friends in doing secret passing as stated by Fauset (1969, pp. 224225 in Sollors, 1997, p. 253).

Angela also humiliates Miss Powell, the black participant in the art class, who wants to talk to Angela while she is waiting for Roger: "She laid her hand on Angela's arm but the latter shook her off. Roger must not see her on familiar terms like this with a coloured girl" (Fauset, n.d., p. 149). Angela lightly thinks that she can ask Miss Powell's forgiveness tomorrow without fully realizing that she has hurt Miss Powell's feeling and pride.

Angela refuses Anthony Cross' deep love for her. Anthony is one of the participants in the art class. Compared to Roger, Anthony is the opposite "a very serious, almost sad young man" (Fauset, n.d., p. 99). He is very romantic and true to his feeling "I'm so content to be with you, Angel. I may call you Angel, mayn't I? You are to me, you know. Oh if you only knew how happy it makes me to be content, to be satisfied like this" (Fauset, n.d., p. 141). However, he cannot offer a life in luxury for Angela "Could you for the sake of love, for the sake of being loyal to the purposes and vows of someone you loved, bring yourself to endure privation and hardship and misunderstanding" (Fauset, n.d., p. 142). Angela, who "go out to seek life and happiness" (Fauset, n.d., p. 143) in NY, cannot take a life in poverty and sacrifice as offered by Anthony although deep down in her heart she likes him very much and she feels that "A woman could be her true self with him" (Fauset, n.d., p. 147). Thus Angela puts aside her feeling for Anthony for the easy life offered by Roger.

Another impact of her relationship with Roger is that she loses her interest in studying how to paint seriously. After being abandoned by Roger, Angela does her painting seriously but she has to face the reality that she needs a job to support herself in NY because her money is running out. The sensitive instructor in the art class offers a job with a relatively good pay (Fauset, n.d., p. 237). For the time being, Angela is saved from the financial problem but still she is lonely because all of the few people that she knows in NY are busy with their own life.

\section{Angela's Confession of her Racial Origin}

After her relationship with Roger ends humiliatingly, Angela focuses on her painting lesson and she progresses amazingly. She begins to make new friendship and tries to sympathize with their problems. However, she still feels alone and lonely. She compares her life now and her black sister's: "Jinny had changed her life and been successful. Angela had changed hers and had found pain and unhappiness. Where did the fault lie? Not, certainly, in her determination to pass from one race to another" (Fauset, n.d., p. 245). Angela also remember her mulatto mother's wise words: "Life is more important than colour" (Fauset, n.d., p. 268). Angela begins to realize how selfish she is all this time "she had been too intent always on happiness for herself. Her father, her mother and Jinny had always given and she had always taken" (Fauset, n.d., p. 277). Angela also remembers about Rachel Salting, her apartment mate, who is willing to sacrifice for her love to the man she intends to marry 
(Fauset, n.d., p. 249). In her loneliness, Angela starts to contemplate her messy life. Angela's messy life as the result of her selfish decision corresponds to Hudson's opinion (2008) that the passers will face difficulties to belong to the white or black communities due to their previous egoistic choice.

The contemplation results in Angela's decision to amend for her big mistake to Virginia, Anthony Cross, and Miss Powell. The first action done by Angela to realize her intention to atone for her guilt is to see Anthony Cross. Angela begins to realize that she loves Anthony "for himself, for his sincerety, for his fierce pride, for his poverty, for his honest, frantic love" (Fauset, n.d., p. 266). Angela decides that she is willing "to be poor with Anthony; to struggle with him" (Fauset, n.d., p. 274). However, her plan to win back Anthony's love does not run smoothly. First, Anthony doubts her intention: "I've been away from you so long I had forgotten ... Forgotten how dangerous you are. Forgotten how a woman like you plays with poor fool like me" (Fauset, n.d., p. 281) although he is still deeply in love with her "Angel, Angel, I shall love you always. Life cannot rob me of that. Good-bye, my sweetest" (Fauset, n.d., p. 284). Then Anthony misinterprets Angela's reaction when he confesses that actually he is coloured, not white: " "Because I'm coloured." In her bewildered relief she fell away from him" (Fauset, n.d., p. 287). Anthony thinks that Angela despises him. When Angela gets a chance to tell him that she is coloured too (Fauset, n.d., p. 299), there is another problem because Anthony says unexpectedly "But I'm engaged" (Fauset, n.d., p. 301) and the irony is that he is engaged to Virginia, Angela's black sister. They meet when Virginia feels devastated after being abandoned by Angela in NY railway station (Fauset, n.d., p. 304). These two suffering people find solace to each other. To Virginia, Anthony is "I'm God to her" (Fauset, n.d., p. 303), and to Anthony, Angela is "You are God to me" (Fauset, n.d., p. 303). In this ironical situation, Angela "tore herself from him. "No, I took her sister away from her; I won't take her lover. Kiss me good-bye, Anthony"' (Fauset, n.d., p. 307). Angela does not want to hurt her younger sister anymore.

Feeling that she has lost Anthony forever, Angela does not want to lose her sister too. Her relationship with Virginia is getting better although it is not as close as previously when they were still in Philadelphia: "They would always view each other from the two sides of an abyss, narrow but deep, deep" (Fauset, n.d., p. 317). However, it turns out that actually Virginia, who is engaged to Anthony, has her own secret "I'll make him happy too, but, oh, Angela, Angela, I always wanted to marry Matthew" (Fauset, n.d., p. 318). Matthew Henson is a guy from the old days in Philadelphia whom Virginia secretly loves but who is crazily in love with Angela. To help Virginia meet her true love, Angela visits Matthew in Philadelphia and surprisingly Matthew confesses that he secretly loves Virginia "I fell in love with Jinny" (Fauset, n.d., p. 370) but he cannot express his love to Virginia because he thinks she regards him as a big brother only "she made it so plain all the time that she looked on me as her sister's beau and therefore a kind of dependable brother" (Fauset, n.d., p. 370). Virginia gives a hint to Matthew that the fact is different "I know she likes 
you very, very much. And I don't think she regards you as a brother" (Fauset, n.d., p. 371) and urges Matthew to visit Virginia in NY.

Angela's another effort to make amends to her mistake is to help Miss Powell who gets unfair treatment. Both Angela and Miss Powell win the Art Competition and get the awards to study in France, however the award for Miss Powell is cancelled due to her being coloured (Fauset, n.d., p. 337). When Angela visits Miss Powell's house to show her sympathy, she sees that Miss Powell is being cornered by four racist journalists (Fauset, n.d., p. 343). Unable to keep her temper for the humiliation, Angela bravely says that she refuses the award "for the same reason" (Fauset, n.d., p. 348) because "I mean that if Miss Powell isn't wanted' I'm not wanted either. You imply that she's not wanted because she's coloured. Well, I'm coloured too" (Fauset, n.d., p. 349). Angela publicly in front of the racist journalists says loudly that she is coloured not white.

Angela's confession brings two opposite impacts. The negative impact is that she is directly fired from her job (Fauset, n.d., p. 354). This negative impact is in accordance with Khanna's research (2001) about the consequence that the passing person must endure if the secret is discovered; that is, a ruthless turning point without any chance to return to the white community (p. 55). Khanna's opinion is also in line with Hobbs (2014) who states that the person passing as white must leave the white society where he/she belongs before after being discovered (p.11). However, there are also positive impacts. Virginia, deeply moves by Angela's public confession followed by its inevitable consequences, warm- ly welcomes Angela:

"It's because you are a fool that I am crying," said Jinny sobbing and sniffing, her fingers in her eyes. "You're a fool and the darlingest girl that ever lived, and my own precious, lovely, wonderful sister back again. Oh, Angela, I'm so happy" (Fauset, n.d., p. 352).

Virginia is so happy because Angela's daring confession shows that she acknowledges her black racial heritage which means that she is the same as Virginia. Angela's public confession reunites her with her younger sister.

Virginia urges Angela to keep going to France as planned because that is Angela's dream as a painter (Fauset, n.d., p. 352) and she will provide financial support whenever Angela needs it (Fauset, n.d., p. 361). At last, Virginia, who always cares and loves her sister, also sends Anthony to Paris to meet Angela on Christmas as a surprise love gift:

Anthony sitting on the tremendously disproportionate tan and maroon sofa rose to meet her.

His eyes on her astonished countenance, he began searching about in his pockets, slapping his vest, pulling out keys and handkerchiefs. "There ought to be a tag on me somewhere," he remarked apologetically, "but anyhow Virginia and Matthew sent me with their love" (Fauset, n.d., p. 382).

Virginia has been united with her true love, Mathew Henson, and she wants Angela to have a happy life with Anthony Cross, Angela's true love, so that the four of them can taste happiness after years of hurts and sufferings. 


\section{CONCLUSIONS}

In a still racist society of the 1930 s America, skin colour has an important role. Being white means having a lot of chances and privileges while being blacks means limited chances and privileges. For those black descendants who have light skin they have a chance to pass as whites and enjoy a life with wider opportunities. However, not all light-skinned people can have an easy life after successfully passing as whites whether temporarily or permanently.

Jessie Redmon Fauset in her novel entitled Plum Bun portrays the life of a lightskinned female protagonist called Angela Murray who changes her name into Angéle Mory when she passes permanently as white. In order to realize her dream of having a more fulfilling life in a white society with a white partner, she hurts many people including her own younger sister who is black, another black female participant in the art school, and the poor man she actually loves. Unable to find true happiness, being humiliatingly abandoned by the white lover, realizing that she cannot become herself in the white society, and deciding to atone for her past mistakes, Angela makes a public confession about her true racial heritage. Her daring action results in happiness in the form of a sister, friends, and a true lover.

Through her novel, Fauset wants to convey the message that "Life is more important than colour" (Fauset, n.d., p. 268), which are the wise words uttered by Angela's and Virginia's mulatto mother who has a lot of experience of life. Happiness and comfort are not determined by skin colour. Being true to one own self and always appreciating others, whatever their skin colour is, give more comfort than living in deceit by denying the true skin colour. Life in its fullest sense can be enjoyed by anyone regardless of their skin colour. A happy life can be constructed by anybody whatever his/her skin colour.

\section{BIBLIOGRAPHY}

Beard, Adrian. (2001). Texts and Contexts: introducing literature and language study. New York: Routledge.

Berzon, Judith R. (1978). Neither White Nor Black. The Mulatto Character in American Fiction. New York: New York University.

Brown, H. Rap. (1969). Die, Nigger, Die!. New York: Dial Press. p. 2.

DiAngelo, Robin. "White Fragility". In International Journal of Critical Pedagogy, Vol 3 (3) (2011) pp 54-70

Fauset, Jessie Redmon. (n.d.). Pum Bun. New York: FrederickA. Stokes Company. (https://ia802708.us.archive. org/ 12 /items / plumbunnovel with00fausrich/plumbunnovelwith 00fausrich.pdf accessed May 16, 2015).

Fauset. Jessie Redmon. (1933 rpt 1969). Comedy: American Style. College Park, M.D.: Mc Grath Publishing. p. 224-225. Hobbs, Allyson. (2014). A Chosen Exile A History of Racial Passing in American Life. Cambridge, Massachusetts: Harvard University Press. (http://bookzz.org/ book/2458037/61aab4 accessed June 14, 2015).

Hudson, Elisabeth. "The Relationship Between Colour and Identity in the Literature of Nella Larsen and Richard Wright". In Lethbridge Undergraduate Research Journal. Volume 3 Number 2. 2008.

Humm, Maggie. (1995). The Dictionary of Feminist Theory. Second edition. Co- 
lumbus: Ohio State University Press. Kennedy, Randall. "Racial Passing". In Ohio State Law Journal [Vol. 62: 1145 (2001)]

Khanna, Nikki. (2011). Biracial in America. Forming and Performing Racial Identity. Lanham, Maryland: Lexington Books (http://gen.lib.rus.ec/book/index.php? md5=389B3F1D2AC48250B995D1 E677665F84 accessed May 21, 2015).

Sollors, Werner. (1997). Neither Black Nor White Yet Both. Thematic Explorations of Interracial Literature. Oxford: OUP Stonequist, Everett V. (1937 rpt 1961). The Marginal Man: A Study in Personality and Culture Conflict. New York: Russell \& Russell, Inc. p. 221.

Wald, Gayle. (2000). Crossing the Line Racial Passing in Twentieth-Century U.S. Literature and Culture. Durham and
London: Duke University Press. (http:// bookzz.org/book/812331/6af1af accessed June 14, 2015).

Williams, Teresa Kay. (2004). "Race-ing and being Raced: The Critical Interrogation of 'Passing'" in Mixed Race Studies: A Reader. Ed. Jayne O. Ifekwunigwe. London: Routledge. pp. 1-29. (http://gen.lib.rus.ec/book/index. php?md5=15A7F97AC8788ADDE 95A1500F507AB08 accessed $27 \mathrm{Mei}$ 2015).

Wirth, Louis, and Goldhamer, Herbert. (1944). "The Hybrid and the Problems of Miscegenation" and "Legal Restrictions on Negro-White Intermarriage" in Characteristics of the American Negro, ed. Otto Klineberg. New York: Harper and Row. 